\author{
Ю.О. Подчашинський, д.т.н., проф. \\ Ю.О. Шавурський, к.т.н., доц. \\ Л.О. Чепюк, к.т.н. \\ Т.С. Воронова, асистент \\ Д.В. Макарчук, студент \\ Державний університет «Житомирська політехніка»
}

\title{
Системний аналіз та формулювання вимог до метрологічного забезпечення інформаційно-вимірювальної системи резервуарних парків нафтопродуктів
}

\begin{abstract}
Застосування інформаційно-вимірювальних систем у нафтогазовій галузі допомагає знизити вартість виробництва та зберігання нафтопродуктів, зменшити використання енергоресурсів, a також знизити витрати на технічний персонал за рахунок збільшення вірогідності $i$ швидкості одержання інформації, необхідної для прийняття управлінських рішень. Основне призначення резервуарного парку - це приймання $i$ зберігання нафти. Впровадження інформаційно-вимірювальної системи резервуарним парком допоможе значно зменшити роботу технічного персоналу, знизити витрати на ремонт обладнання за рахунок збільшення міжремонтного періоду, а також покращити якість нафтопродуктів за допомогою постійного контролю за технологічними прочесами, автоматизованого управління обладнанням $i$ апаратурою, а також швидкого усунення виниклих неполадок системи або в разі аварійних ситуацій. Найважливішими параметрами при зберіганні нафти є рівень нафти в резервуарах, тиск у трубопроводi, а також температура. Інформаційно-вимірювальна система резервуарних парків нафтопродуктів дозволяє стежити за цүими показниками за допомогою сучасних польових датчиків $i$ програмованих локальних контролерів, а також дає можливість регулювати иі параметри за допомогою виконавчих механізмів. Інформаційно-вимірювальна система (IBC) резервуарних парків нафтопродуктів має складатися з розподіленої системи управління (РСУ) і автоматичної системи протиаварійного захисту (ПАЗ).
\end{abstract}

Ключові слова: інформаційно-вимірювальна система; системний аналіз; метрологічне забезпечення; вимірювальний канал; резервуарний парк.

Актуальність теми. Застосування інформаційно-вимірювальних систем у нафтогазовій галузі допомагає знизити вартість виробництва та зберігання нафтопродуктів, зменшити використання енергоресурсів, а також знизити витрати на технічний персонал за рахунок збільшення вірогідності і швидкості одержання інформації, необхідної для прийняття управлінських рішень.

Аналіз останніх досліджень та публікацій, на які спираються автори. Інформаційновимірювальні системи кількісного обліку нафти та нафтопродуктів на об'єктах зберігання (нафтобазах і резервуарних парках) розглянули у книгах Алієв Т.М., Тер-Хачатуров А.А. [1, 2], Калінов Г.А., Рімлянд В.I., Казарбін А.В. [3] та Зайцев Л.А., Панарін В.В. [4]. Питання проєктування, монтажу, налагодження та експлуатації систем збору i обробки первинної інформації в нафтогазовій промисловості розглянули у працях Шаловніков Е.А. [5], Срмоленко, А.Д. [6], Громаков Є.І., Лієпіньш А.В. [7], Дранчук М.М. [8] та ін.

Метою статті $\epsilon$ системний аналіз структури та формулювання вимог до метрологічного забезпечення інформаційно-вимірювальної системи резервуарних парків нафтопродуктів.

Викладення основного матеріалу.

Системний аналіз вимог до функціонування та метрологічного забезпечення IBC

Основне призначення резервуарного парку - це приймання і зберігання нафти. Впровадження інформаційно-вимірювальної системи резервуарним парком допоможе значно зменшити роботу технічного персоналу, знизити витрати на ремонт обладнання за рахунок збільшення міжремонтного періоду, а також покращити якість нафтопродуктів за допомогою постійного контролю за технологічними процесами, автоматизованого управління обладнанням і апаратурою, а також швидкого усунення виниклих неполадок системи або в разі аварійних ситуацій.

Найважливішими параметрами при зберіганні нафти $€$ рівень нафти в резервуарах, тиск у трубопроводі, а також температура. Інформаційно-вимірювальна система дозволяє стежити за цими показниками за допомогою сучасних польових датчиків і програмованих локальних контролерів, а також дає можливість регулювати ці параметри за допомогою виконавчих механізмів.

Інформаційно-вимірювальна система (IBC) резервуарних парків нафтопродуктів має складатися 3 розподіленої системи управління (РСУ) і автоматичної системи протиаварійного захисту (ПАЗ). 
IBC резервуарних парків нафтопродуктів повинна мати трирівневу структуру:

- нижній рівень - рівень розміщення контрольно-вимірювальних приладів (КВП) і виконавчих механізмів - враховує в себе польове обладнання, встановлене на технологічних трубопроводах $\mathrm{i}$ апаратах;

- середній рівень - рівень збору інформації з нижнього рівня, видачі керуючих впливів на виконавчі механізми, пристрої прийому / передачі даних на верхній рівень;

- верхній рівень - рівень, що містить серверну шафу і автоматизовані робочі місця (АРМ). На цьому рівні забезпечується доступ до технологічної інформації для обслуговуючого, технологічного персоналу, інженерно-технічних працівників і адміністративно-управлінського персоналу.

Вимоги до функиій (завдань), щяо виконуються IВС. Основні функиії РСУ:

- збір, обробка та відображення для технологічного персоналу поточних значень технологічних параметрів і стану обладнання. Відображення технологічного процесу має бути організовано у вигляді мнемосхем, таблиць, екранних полів різного призначення в реальному масштабі часу;

- видача керуючих впливів на виконавчі механізми і обладнання відповідно до заданих алгоритмів управління і регулювання або за завданням оператора;

- формування звітів, автоматичний облік сировинних, продуктових і допоміжних потоків на межі установки;

- відображення для технологічного персоналу сигналізації про вихід технологічних параметрів за допустимі значення і про зміну стану обладнання;

- накопичення інформації про значення технологічних параметрів, про стан обладнання, сигналізації і дії оператора в довготривалій пам'яті за проміжок часу, який конфігуруеться;

- реєстрація спрацьовування і контроль над працездатним станом засобів ПАЗ;

- видача необхідної інформації в систему вищого рівня;

- можливість внесення змін у конфігурацію системи в режимі «онлайн» (без зупинки процесу управління і без внесення збурень у контури управління і блокування, яких не стосуються зміни);

- можливість заміни обладнання, яке відмовило, і додавання нових вузлів і плат без відключення живлення;

- можливість синхронізації точного часу;

- цикл виконання, встановлений для кожного з алгоритмів управління, моніторингу та блокування, має бути фіксованим (незалежним від розміру програми).

Система має бути орієнтована на роботу в жорсткому режимі реального часу, тобто на забезпечення виконання всіх заданих функцій із заданою періодичністю і в заданий термін.

Система протиаварійного захисту (ПАЗ) повинна забезпечувати захист персоналу, технологічного обладнання і навколишнього середовища в разі виникнення нештатної ситуації, розвиток якої може призвести до аварії.

ПАЗ функціонує незалежно від РСУ. Порушення роботи РСУ не має впливати на роботу ПАЗ. ПАЗ має виконувати такі функції:

- автоматичне виявлення потенційно небезпечних змін стану технологічного об’єкта або РСУ;

- автоматичне вимірювання технологічних змінних, важливих для безпечного ведення технологічного процесу (наприклад, вимір змінних, значення яких характеризують близькість об'єкта до межі режиму безпечного ведення процесу);

- автоматична (в режимі «онлайн») діагностика відмов, що виникають у ПАЗ і (або) в використовуваних нею засобах технічного і програмного забезпечення (ПЗ);

- автоматична передаварійна сигналізація, яка інформує оператора технологічного процесу про потенційно небезпечні зміни, що відбулися в об'єкті або в ПАЗ;

- автоматичний захист від несанкціонованого доступу до параметрів настройки і (або) вибору режиму роботи ПАЗ

Команди від ПАЗ повинні мати пріоритетну дію на виконавчі механізми по відношенню до команд від РСУ. Інформація про роботу ПАЗ має передаватися в РСУ і виводитися на екран на АРМ оператора, заноситися в пам'ять, протоколи ії роботи повинні друкуватися. Спрацьовування блокувань мають реєструватися із зазначенням часу. Виконання ПАЗ має відповідати всім вимогам техніки безпеки. Повинні бути передбачені сервісні ключі (реалізовані програмно) для заміни, ремонту та повірки блокувальних датчиків.

Для аналогових модулів введення / виведення має бути забезпечена функція визначення обриву, замикання лінії і виходу параметра за межі діапазону.

Вимоги до метрологічного забезпечення IBC

Повна приведена похибка модулів каналів аналогового введення без урахування первинного приладу (датчика, вимірювального перетворювача) не повинна перевищувати $\pm 0,2 \%$. При розрахунку похибки мають враховуватися всі елементи, що входять до вимірювального ланцюга (модулі, бар'єри і тощо). 
Вимоги до математичного та програмно-алгоритмічного забезпечення IBC

Алгоритми, що входять до складу математичного забезпечення системи, мають володіти повнотою (охоплювати всю сукупність технологічних процесів і їх взаємодію між собою), чіткістю (включати в себе всі можливі варіанти результату тих чи інших ситуацій) і передбачати виконання всіх функцій системи.

В межах математичного забезпечення мають бути розроблені такі алгоритми:

- алгоритми протиаварійних захистів;

- алгоритми регулювання параметрів технологічних процесів;

- алгоритми управління виконавчими механізмами;

- алгоритми, що запобігають розвитку аварійних ситуацій;

- алгоритми розрахунку техніко-економічних показників роботи агрегату.

Аварійна ситуація повинна бути визначена при досягненні параметра аварійної межі. У тих випадках, де фізичний параметр контролюється кількома датчиками, визначення аварійної ситуації має грунтуватися на вимірах як мінімум двох датчиків (дискретних або аналогових).

Передаварійна ситуація - досягнення змінної по аналоговому сигналу технологічної межі або поява відповідного дискретного сигналу - має передбачати тільки повідомлення оператору без автоматичного управління виконавчими механізмами.

Алгоритми протиаварійних захистів повинні становити собою послідовність дій на виконавчі механізми з контролем за їх виконанням в автоматичному режимі для запобігання виникнення аварії.

Алгоритми регулювання технологічних параметрів мають забезпечувати оптимальні режими роботи агрегату.

Алгоритми управління виконавчими механізмами повинні становити собою послідовність дій для дистанційного керування, враховуючи блокування на відключення і заборону на включення (відкриття, закриття), якщо хоча б одна $з$ умов відключення виконується або результат впливу може привести до порушення режиму функціонування окремих об'єктів і установки в цілому.

Алгоритми, що запобігають розвитку аварійних ситуацій, мають становити собою послідовність дій управління виконавчими механізмами, зміну параметрів ведення технологічного процесу тощо 3 метою стабілізації роботи агрегату в разі порушення нормального технологічного режиму, але параметри не досягнули аварійних значень.

В алгоритмах також має бути передбачене автоматичне включення резерву технологічного обладнання (там, де це потрібно).

Пі час розробки математичного забезпечення мають бути враховані процедури діагностики програмних і технічних засобів системи управління.

Вимоги до програмного забезпечення РСУ і ПАЗ

Програмування контролерів має виконуватися на стандартних мовах програмування. Прикладне програмне забезпечення (ПЗ) РСУ має відповідати стандарту ДСТУ EN 61131-2:2017 [9]. Система повинна мати повний набір апаратного і програмного забезпечення для створення i редагування апаратної конфігурації та баз даних системи. При цьому має забезпечуватися можливість завантаження змінених або створених програм в окремі вузли при роботі системи без порушення іiі роботи.

ПЗ розподільної системи управління повинно забезпечувати виконання таких функцій:

- відображення на мнемосхемах АРМ даних про стан технологічного процесу і обладнання;

- обчислення змінних, масштабування, арифметичні операції, лінеаризація (таблична або поліномами);

- управління контурами регулювання: ПІД-регулювання, каскадне ПІД-регулювання, регулювання співвідношення, двопозиційне регулювання, виконання послідовності операцій за алгоритмом;

- функції і алгоритми вдосконаленого управління процесом.

Включення в роботу вказаних вище функцій має здійснюватися шляхом конфігурації, тобто внесення параметрів в екранні форми, без програмування в текстовому вигляді або на «низькому» рівні.

Всі змінні, одержувані по цифрових каналах, мають бути доступні в прикладних програмах i алгоритмах РСУ. До складу ПЗ враховуються всі необхідні ліцензії на кількість параметрів, які конфігуруються, $+20 \%$ резерв.

Під час програмування ПАЗ допускається використання тільки стандартних методів програмування (наприклад, функціональні логічні схеми або релейна багатоланцюгова логічна схема). Програмування в мнемонічних символах і на мові високого рівня не допускається.

Налаштування рівнів спрацьовування сигналізації для аналогових входів, настройка таймерів, конфігурація нормально відкритого / нормально закритого режиму для цифрових входів / виходів, мають здійснюватися програмно.

В системі ПАЗ повинні бути передбачені засоби формування вихідних сигналів тривоги.

Сигнали тривоги ПАЗ мають охоплювати відмову джерел живлення, несправність центрального процесора тощо. У РСУ повинні передаватися тільки загальні сигнали тривоги. 
У логічних схемах реалізація функцій управління і захистів має бути виконана на базі логічних елементів. В ПАЗ повинні формуватися вихідні сигнали аварійного відключення електрообладнання, закриття/ відкриття запірної і відсічних арматур. Після спрацьовування блокування і повернення параметра в нормальний стан скидання відображення аварійного параметра на АРМ оператора відбувається автоматично. Перезапуск електрообладнання та відкриття / закриття запірної і відсічних арматур виробляється оператором.

Вимоги до програмного забезпечення АРМ оператора

На АРМ оператора має бути забезпечено виведення на мнемосхеми інформації про технологічний процес і стан обладнання в текстовому вигляді (значення параметрів, повідомлення) і графічному вигляді (тренди, анімація, гістограми тощо).

Має бути забезпечена побудова трендів з кількістю параметрів не менше 8 на одному графіку.

Всі написи і повідомлення на мнемосхемах операторів повинні бути виконані українською мовою. Системні і діагностичні повідомлення, призначені для інженера РСУ і ПАЗ, можуть виконуватися англійською мовою.

Всі станції операторів мають бути взаємозамінними і забезпечувати управління будь-яким блоком технологічної установки. 3 будь-якої станції оператора повинен забезпечуватися доступ до всіх даних у системі, враховуючи дані реального часу, історичні дані, тренди, журнали сигналізацій тощдо. Відмова будь-якої станції не має обмежувати функції регулювання і моніторингу, що виконуються системою.

В системі повинна забезпечуватися можливість отримання даних станціями оператора безпосередньо від контролерів, без проміжних серверів

Час оновлення даних на мнемосхемах АРМ операторів має бути не більше однієї секунди.

Вимоги до програмного забезпечення АРМ інженера РСУ $і$ ПАЗ

Звернення до всіх змінних в РСУ і ПАЗ повинно виконуватися по символьному імені без вказівки фізичної адреси. Система повинна мати розвинений інструментарій для розробки і конфігурації мнемосхем і звітів. РСУ і ПАЗ має забезпечувати конфігурацію контурів і алгоритмів керування для виконання різних завдань. Редагування і зміна мнемосхем і алгоритмів керування на діючому обладнанні має бути забезпечено без зупинки, перезавантаження або переривання технологічного процесу. Всі зміни в РСУ і ПАЗ повинні виконуватися зі станції інженера РСУ і ПАЗ. Всі зміни мають виконуватися в одному місці і автоматично поширюватися на всі вузли.

Зі станції інженера РСУ і ПАЗ має виконуватися резервне копіювання і відновлення бази даних системи. Копіювання має виконуватися автоматично за розкладом або на вимогу. Повинна забезпечуватися можливість копіювання бази даних на зовнішній носій.

Вимоги до програмного забезпечення АРМ інженера КВП

Програмне забезпечення станції інженера КВП повинно забезпечувати ведення бази даних приладів, 3 реєстрацією виявлених відмов і несправностей, проведеного технічного обслуговування, ремонтів та калібрування.

Розробка структурної схеми IBC

Структурна схема комплексу технічних засобів інформаційно-вимірювальної системи резервуарних парків нафтопродуктів побудована за трирівневим ієрархічним принципом.

- нижній рівень містить польове обладнання, встановлене на технологічних трубопроводах $\mathrm{i}$ апаратах;

- середній рівень - рівень збору інформації з нижнього рівня, видачі керуючих впливів на виконавчі механізми пристрою прийому передачі даних на верхній рівень і враховує в себе:

1) кросові шафи;

2) шафи автоматизації;

- верхній рівень - рівень автоматизованого оперативного управління, що містить серверну шафу, автоматизовані робочі місця (АРМ):

1) АРМ старшого оператора;

2) два АРМ оператора-технолога;

3) АРМ машиніста насосного обладнання;

4) АРМ інженера РСУ і ПАЗ;

5) АРМ інженера КВП;

6) АРМ панелей візуалізації.

На цьому рівні забезпечується доступ до технологічної інформації для обслуговуючого, технологічного персоналу, інженерно-технічних працівників і адміністративно-управлінського персоналу.

Нижній рівень системи складається з первинних засобів автоматизації:

- первинні і позащитові прилади:

1) датчики тиску;

2) датчики рівня; 
3) датчики температури;

4) датчики витрати;

5) газоаналізатори;

- виконавчі пристрої і механізми:

1) пости сигналізації загазованості, що містять:

a) сигналізатори звукові;

б) сигналізатори світлові;

в) пости кнопкові;

2) пневмоприводні клапани, що враховують:

а) електропневматичні позиціонери;

б) сигналізатори кінцевих положень;

в) електроприводи;

- кабельна продукція;

- модульні вузли управління.

Нижній рівень виконує такі функції: игнал;

- вимірювання параметрів технологічного процесу обладнання і перетворення їх в уніфікований

- збір і передача інформації про хід технологічного процесу і стан технологічного обладнання на середній рівень;

- виконання команд регулювання і управління, що надходять із середнього рівня;

- формування світлових і звукових попереджувальних і передаварійних сигналів.

Середній рівень системи складається з програмованих логічних контролерів (ПЛК) РСУ і ПАЗ, джерел безперебійного живлення (ДБЖ), кросових шаф і контролерної мережі RS-485 (Modbus RTU).

Середній рівень системи виконує такі функції:

- збір, первинна обробка (фільтрація, лінеаризація і масштабування) і контроль інформації про стан обладнання та параметри технологічного процесу;

- автоматичне керування технологічним обладнанням;

- регулювання параметрами технологічного процесу; виконання команд, що надходять 3 верхнього рівня;

- формування керуючих впливів на виконавчі механізми системи;

- обмін інформацією з верхнім рівнем;

- підтримка єдиного часу в системі;

- $\quad$ робота в автономному режимі пі час порушення зв'язку з верхнім рівнем;

- формування попереджувальних і передаварійних сигналів;

- автоматична діагностика комплексу програмних і технічних засобів;

- безперебійне живлення технічних засобів середнього рівня.

Верхній (інформаційно-обчислювальний) рівень системи складається з брандмауера, серверів баз даних (основного і резервного), комутаторів, ДБЖ і АРМ.

Верхній рівень системи виконує такі функції:

- $\quad$ прийом інформації про стан обладнання та параметри технологічного процесу з середнього рівня системи;

- формування і оперативне відображення інформації в реальному масштабі часу у вигляді мнемосхем 3 динамічними елементами, таблиць і графіків, що відображають поточний стан технологічного процесу;

- формування та ведення технологічної бази даних;

- вибірка інформації з бази даних реального часу, вибірка і пошук інформації в історичній i архівній базі даних;

- формування та відображення протоколів подій;

- формування і видача команд дистанційного керування;

- обмін даними із середнім рівнем системи;

- друк звітної документації, зведень, трендів, протоколів подій, переліків несправностей i/або відмов;

- безперебійне живлення технічних засобів верхнього рівня.

Структурна схема комплексу технічних засобів інформаційно-вимірювальної системи резервуарних парків нафтопродуктів зображена на рисунку 1. 


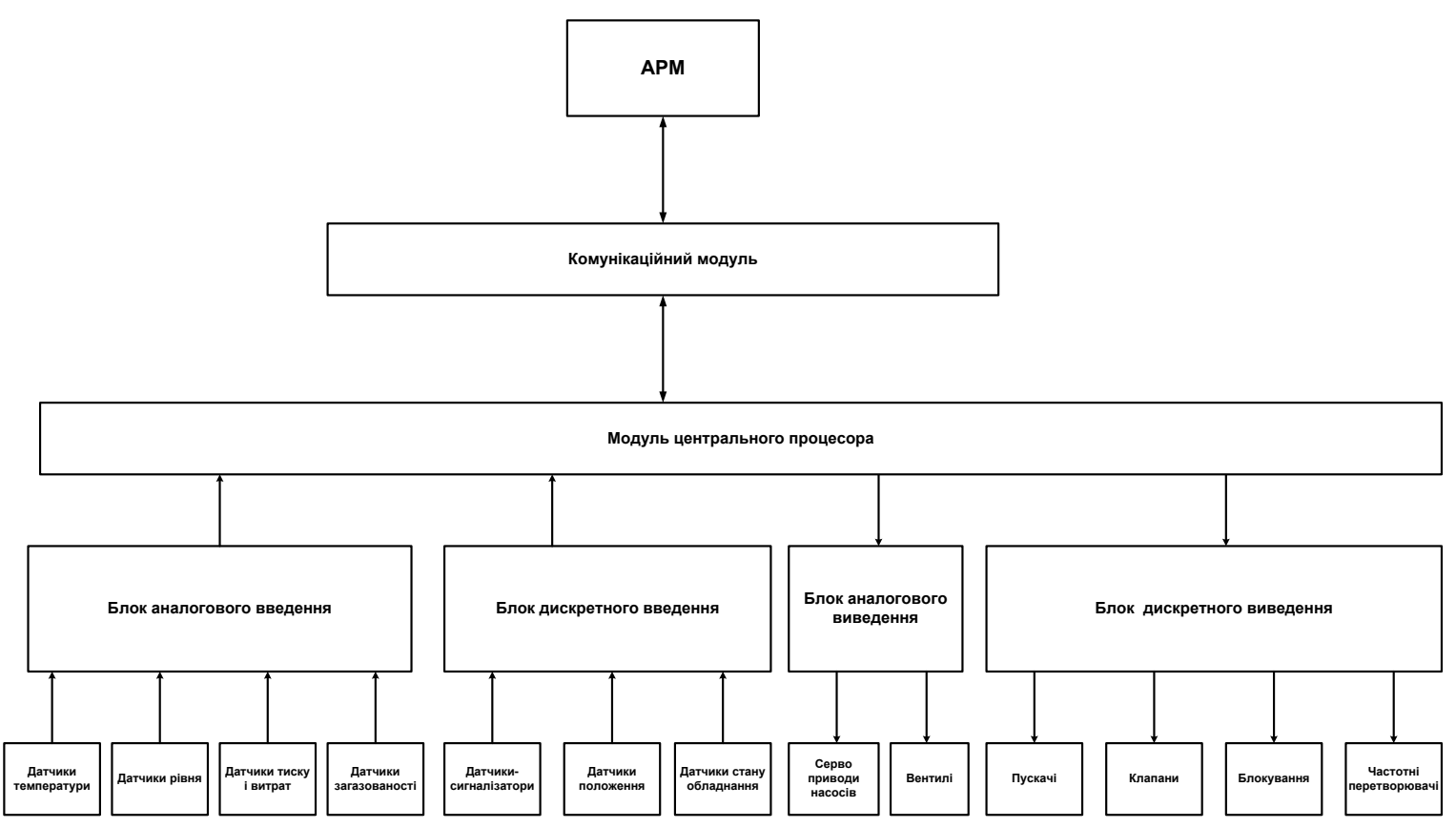

Рис. 1. Структурна схема комплексу технічних засобів інформаційно-вимірювальної системи резервуарних парків нафтопродуктів

\section{Нормування похибки каналу вимірювання}

Нормування похибки каналу вимірювання виконується відповідно до ДСТУ-Н РМГ 62:2006 Метрологія. Забезпечення ефективності вимірювань під час керування технологічними процесами. Оцінення похибки вимірів у разі обмеженої вихідної інформації [10].

Розглянемо приклад розрахунку похибки каналу вимірювання. Як канал вимірювання виберемо канал вимірювання витрат. Вимога до похибки каналу вимірювання не більше за 0,2%. Розрядність АЦП становить 16 розрядів.

Розрахунок допустимої похибки вимірювань витратоміра здійснюється за формулою (1):

$$
\delta_{1} \leq \sqrt{\delta^{2}-\left(\delta_{2}^{2}+\delta_{3}^{2}+\delta_{4}^{2}+\delta_{5}^{2}+\delta_{6}^{2}+\delta_{7}^{2}\right)},
$$

де $\delta=0,2 \%$ - необхідна сумарна похибка вимірювання каналу вимірювань при довірчій ймовірності 0,95 ;

$\delta_{2}$ - похибка передачі по каналу вимірювань;

$\delta_{3}$ - похибка, яку вносить АЦП;

$\delta_{4}, \delta_{5} \delta_{6} \delta_{7}$ - додаткові похибки, що вносяться температурою навколишнього повітря, перешкодами різного виду, тиском вимірюваного середовища та іншими факторами відповідно.

Похибка передачі по каналу вимірювання встановлюється рекомендаціями [10]:

$$
\delta_{2}=\frac{0,2 \cdot 4}{100}=0,008 \% \text {. }
$$

Похибка, що вноситься 16-розрядним АЦП, розраховується таким чином:

$$
\delta_{3}=\frac{0,2 \cdot 100}{2^{16}}=0,0003 \% .
$$

Під час розрахунку також враховуються додаткові похибки, викликані впливом:

- температури навколишнього повітря;

- перешкод різного виду;

- тиску вимірюваного середовища;

- інших факторів.

Додаткова похибка, яку вносить вплив температури навколишнього повітря, встановлюється рекомендаціями [10]:

$$
\delta_{5}=\frac{0,2 \cdot 1}{100}=0,002 \% .
$$

Додаткова похибка, яку вносить перешкоди різного виду, встановлюється рекомендаціями [10]: 


$$
\delta_{5}=\frac{0,2 \cdot 1}{100}=0,002 \% .
$$

Додаткова похибка, яку вносить тиск вимірюваного середовища, встановлюється рекомендаціями [10]:

$$
\delta_{6}=\frac{0,2 \cdot 1}{100}=0,002 \% \text {. }
$$

Додаткова похибка, яку вносять інші фактори, встановлюється рекомендаціями [10]:

$$
\delta_{7}=\frac{0,2 \cdot 36}{100}=0,072 \% \text {. }
$$

Таким чином, підставивши в формулу (1) отримані значення, розрахуємо допустиму основну похибку витратоміра:

$$
\delta_{1}=\sqrt{0,2^{2}-\left(0,008^{2}+0,0003^{2}+0,066^{2}+0,002^{2}+0,002^{2}+0,072^{2}\right)}=0,17 \% .
$$

В результаті розрахунку видно, що основна похибка обраного датчика витрати не перевищує допустимої розрахункової похибки. Отже, прилад придатний для використання.

Розробка алгоритмів роботи IBC

Розробка алгоритмів роботи ІВС переслідує такі цілі:

- підвищення рівня інформованості персоналу і достовірності даних стану технологічного обладнання;

- підвищення якості ведення технологічного режиму і його безпеки;

- підвищення оперативності дій персоналу;

- поліпшення екологічної обстановки на об'єкті;

- підвищення надійності управління об’єктом.

Функціонування алгоритмів дозволяє обробляти вхідні сигнали і команди оператора, що надходять 3 АРМ оператора, а також видавати керуючі впливи на виконавчі механізми і повідомлення оператору.

Вхідною інформацією для алгоритмів є:

- конфігураційні дані ПЛК;

- значення аналогових і дискретних сигналів, що надходять на модулі введення ПЛК з датчиків $\mathrm{i}$ перетворювачів;

- дані, що надходять по інтерфейсу;

- дані, що формуються при управлінні технологічним обладнанням з АРМ оператора.

Крім цього, окремі алгоритми використовують дані, отримані в результаті функціонування інших алгоритмів.

Як приклад розглянемо алгоритм отримання вимірювальної інформації про поточний стан та управління регулюючим клапаном.

Алгоритм призначений для роботи з регулюючим клапаном. Вхідними сигналами є сигнали стану «Дистанційне управління», «Місцеве управління», «Відмова», «Положення клапана». Контроль стану клапана здійснюється вихідним аналоговим сигналом. Якщо сигнали «Дистанційне управління» і «Місцеве управління» активні одночасно, то формується сигналізація «Помилка режиму управління клапаном». Дистанційне управління регулюючим клапаном з АРМ оператора блокується.

При неактивних сигналах «Дистанційне управління» і «Місцеве управління» клапан знаходиться у вимкненому стані.

При активному сигналі «Відмова» формується сигналізація «Відмова приводу клапана».

При активному сигналі «Дистанційне управління» клапан знаходиться в режимі дистанційного управління. У дистанційному режимі клапан управляється вручну або автоматично.

При управлінні клапаном вручну положення клапана задається оператором.

Для переходу клапана в автоматичний режим слід дотримуватися таких умов:

- наявність режиму дистанційного управління;

- відсутність сигналізації «Відмова приводу клапану».

За недотримання будь-якої з умов клапан примусово переходить на управління вручну. Формується сигналізація «Ручне управління». Перехід в автоматичний режим здійснюється командою «Авто». В автоматичному режимі здійснюється регулювання технологічного параметра за ПІД-законом. Введення уставки здійснюється 3 панелі управління клапаном. Налаштування параметрів ПІД-регулятора здійснюється $з$ детальної панелі клапана.

Переведення в ручний режим з автоматичного проводиться командою «Руч».

При активному сигналі «Місцеве управління» клапан знаходиться в режимі місцевого управління. Дистанційне управління регулюючим клапаном з АРМ оператора блокується.

Входами алгоритму є сигнали: типу bool та real:

vlv_fail - стан клапана «Відмова»;

vlv_rem - стан клапана «Дистанційне управління»; 
vlv_loc - стан клапана «Місцеве управління»;

vlv_mask - режим клапана «Маскування» включений;

vlv_auto - режим автоматичного регулювання;

vlv_pos - положення клапана;

vlv_pos_man - значення завдання положення клапана в ручному режимі.

Виходами алгоритму є сигнал типу real:

vlv_pos_out - управляючий сигнал засувки «Завдання положення штоку».

Блок-схема алгоритму управління регулюючим клапаном наведена на рисунку 2.

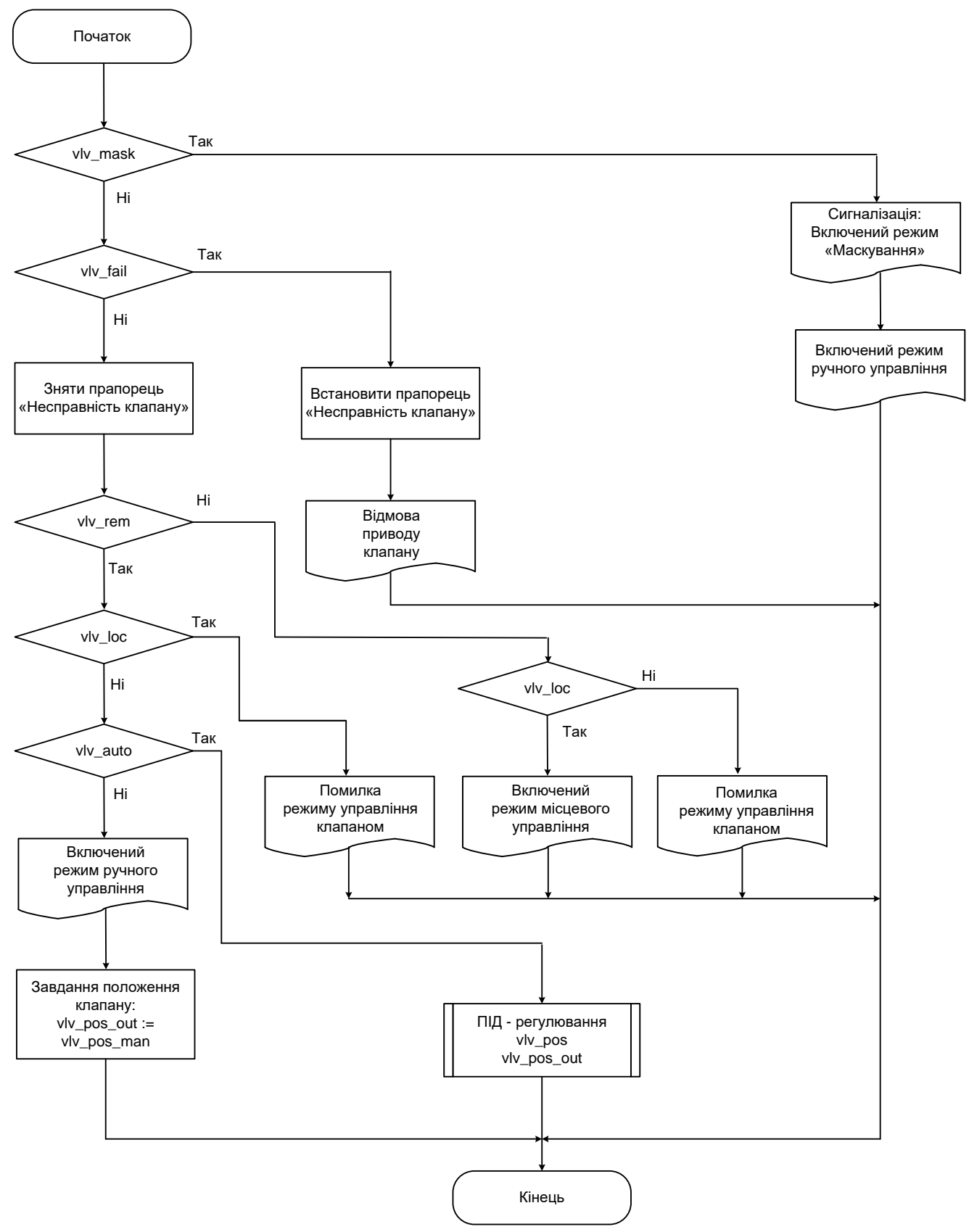

Рис. 2. Блок-схема алгоритму управління регулюючим клапаном

Висновки та перспективи подальших досліджень. Для збільшення ефективності роботи підприємств зі зберігання нафтопродуктів необхідно постійно виконувати оптимізацію і модернізацію виробництва за рахунок зменшення виробничих втрат, технологічних витрат енергоносіїв. Впровадження сучасних інформаційно-вимірювальних систем приводить до збільшення вірогідності і швидкості одержання інформації, яка необхідна для прийняття управлінських рішень [11]. 
Список використаної літератури:

1. Алиев Т.М. Информационно-измерительные системы количественного учета нефти и нефтепродуктов / Т.М. Алиев, А.А. Тер-Хачатуров. - М. : Недра, 1976. - 160 с.

2. Алиев T.M. Измерительно-вычислительные системы количественного учета нефтепродуктов / T.M. Алиев, A.А. Тер-Хачатуров. - М. : Недра, 1984. - 232 с.

3. Калинов Г.А. Системы контроля параметров жидкости в резервуарах и скважинах : монография / Г.А. Калинов, В.И. Римлянд, А.В. Казарбин. - Хабаровск : Тихоокеанский государственный университет, 2019. $-116 \mathrm{c}$.

4. Зайцев Л.А. Система сбора и обработки информации для резервуарных парков / Л.А. Зайцев, В.В. Панарин. М. : Недра, 1984. - 152 с.

5. Основы автоматизации производственных процессов нефтегазового производства : учеб. пособие для студ. учреждений высш. проф. образования / М.Ю. Прахова, Э.А. Шаловников, Н.А. Ииинбаев, С.В. Щербинин ; под ред. М.Ю. Праховой. - М. : Академия, 2012. - 256 с.

6. Автоматизация процессов нефтепереработки / А.Д. Ермоленко, О.Н. Кашин, Н.В. Лисицын и др. - Вологда : Инфра-Инженерия, 2012. - 304 с.

7. Громаков Е.И. Интегрированные компьютерные системы проектирования и управления : учебное пособие / Е.И. Громаков, А.В. Лиепиньш. - Томск : Изд-во Томского политехнического университета, 2013. - $222 \mathrm{c.}$

8. Дранчук М.M. Проектування систем автоматизації технологічних процесів в нафтовій і в газовій промисловості : навчальний посібник / М.М. Дранчук. - Івано-Франківськ : Факел, 2005. - 448 с.

9. ДСТУ EN 61131-2:2017 Контролери програмовані. Частина 2. Вимоги до устаткування та випробування (EN 61131-2:2007, IDT; IEC 61131-2:2007, IDT).

10. ДСТУ-Н РМГ 62:2006. Метрологія. Забезпечення ефективності вимірювань під час керування технологічними процесами. Оцінення похибки вимірів у разі обмеженої вихідної інформації (РМГ 62-2003, IDT).

11. Постанова КМУ № 891 від 22.11.2017 р. «Про затвердження Порядку ведення Сдиного державного реєстру витратомірів-лічильників і рівнемірів - лічильників рівня пального у резервуарі, передачі облікових даних 3 них електронними засобами зв’язку».

\section{References:}

1. Aliev, T.M. and Ter-Khachaturov, A.A. (1976), Informatsionno-izmeritel'nye sistemy kolichestvennogo ucheta nefti i nefteproduktov, Nedra, M., $160 \mathrm{p}$.

2. Aliev, T.M. and Ter-Khachaturov, A.A. (1984), Izmeritel'no-vychislitel'nye sistemy kolichestvennogo ucheta nefteproduktov, Nedra, M., $232 \mathrm{p}$.

3. Kalinov, G.A., Rimlyand, V.I. and Kazarbin, A.V. (2019), Sistemy kontrolya parametrov zhidkosti v rezervuarakh $i$ skvazhinakh, monografiya, Tikhookeanskii gosudarstvennyi universitet, Khabarovsk, 116 p.

4. Zaitsev, L.A. and Panarin, V.V. (1984), Sistema sbora i obrabotki informatsii dlya rezervuarnykh parkov, Nedra, M., $152 \mathrm{p}$.

5. Prakhova, M.Yu., Shalovnikov, E.A., Ishinbaev, N.A. and Shcherbinin, S.V. (2012), Osnovy avtomatizatsii proizvodstvennykh protsessov neftegazovogo proizvodstva, ucheb. posobie dlya stud. uchrezhdenii vyssh. prof. obrazovaniya, in Prakhova, M.Yu. (ed.), Akademiya, M., 256 p.

6. Ermolenko, A.D., Kashin, O.N., Lisitsyn, N.V. et al. (2012), Avtomatizatsiya protsessov neftepererabotki, InfraInzheneriya, Vologda, $304 \mathrm{p}$.

7. Gromakov, E.I. and Liepin'sh, A.V. (2013), Integrirovannye komp'yuternye sistemy proektirovaniya i upravleniya, uchebnoe posobie, Izd-vo Tomskogo politekhnicheskogo universiteta, Tomsk, $222 \mathrm{p}$.

8. Dranchuk, M.M. (2005), Proektuvannja system avtomatyzacii' tehnologichnyh procesiv $v$ naftovij $i$ gazovij promyslovosti, navchal'nyj posibnyk, Fakel, Ivano-Frankivs'k, 448 p.

9. DP «UkrNDNC»(2017), DSTU EN 61131-2:2017 Kontrolery programovani. Vymogy do ustatkuvannja ta vyprobuvannja, Ukrai'na.

10. DP «UkrNDNC» (2006), DSTU-N RMG 62:2006. Metrologija. Zabezpechennja efektyvnosti vymirjuvan' pid chas keruvannja tehnologichnymy procesamy. Ocinennja pohybky vymiriv u razi obmezhenoi' vyhidnoi' informacii' (RMG 62-2003, IDT), Ukrai'na.

11. KMU (2017), «Pro zatverdzhennja Porjadku vedennja Jedynogo derzhavnogo rejestru vytratomiriv-lichyl'nykiv $i$ rivnemiriv - lichyl'nykiv rivnja pal'nogo u rezervuari, peredachi oblikovyh danyh z nyh elektronnymy zasobamy zv'jazku», Postanova No. 891 vid 22.11.2017 r.

Подчашинський Юрій Олександрович - доктор технічних наук, професор, завідувач кафедри метрології та інформаційно-вимірювальної техніки Державного університету «Житомирська політехніка».

Наукові інтереси:

- комп’ютеризовані інформаційно-вимірювальні системи;

- цифрова обробка сигналів і відеозображень;

- системний аналіз складних технічних систем. 
Шавурський Юрій Олександрович - кандидат технічних наук, доцент, доцент кафедри автоматизації та комп'ютерно-інтегрованих технологій ім. проф. Б.Б. Самотокіна Державного університету «Житомирська політехніка».

Наукові інтереси:

- комп'ютеризовані інформаційно-вимірювальні системи;

- цифрова обробка сигналів і відеозображень;

- системний аналіз складних технічних систем.

Чепюк Ларіна Олексіївна - кандидат технічних наук, доцент кафедри метрології та інформаційновимірювальної техніки Державного університету «Житомирська політехніка».

Наукові інтереси:

- комп'ютеризовані інформаційно-вимірювальні системи;

- цифрова обробка сигналів і відеозображень;

- системний аналіз складних технічних систем;

- системи стабілізації.

Воронова Тетяна Станіславівна - доктор технічних наук, професор, асистент кафедри метрології та інформаційно-вимірювальної техніки Державного університету «Житомирська політехніка».

Наукові інтереси:

- комп'ютеризовані інформаційно-вимірювальні системи;

- цифрова обробка сигналів і відеозображень;

- системний аналіз складних технічних систем.

Макарчук Дмитро Вікторович - студент групи МТМ-1мд Державного університету «Житомирська політехніка».

Наукові інтереси:

- комп’ютеризовані інформаційно-вимірювальні системи;

- системний аналіз складних технічних систем. 